\title{
Kinerja Organisasi Publik dalam Mendukung Penyelenggaraan Pelayanan di Kantor Kecamatan Johan Pahlawan
}

\author{
Agatha Debby Reiza Macella \\ Jurusan Ilmu Administrasi Negara, Universitas Teuku Umar, Indonesia.
}

\section{ARTICLE INFORMATION}

Received: February 11, 2020

Revised: April 26, 2020

Accepted: April 28, 2020

Available online: April 30, 2020

\section{KEYWORDS}

Performance, Organization, Public Service

\section{CORRESPONDENCE}

Phone: +6282122698563

E-mail: agathadebby@utu.ac.id
A B S T R A C T

\section{PENDAHULUAN}

Organisasi merupakan sekelompok orang yang bekerjasama secara terpimpin dan terkendali untuk mencapai suatu tujuan tertentu, dengan menggunakan suatu sumber daya tertentu seperti lingkungan, metode, material, mesin, manusia, finansial, dan sumber daya lainnya secara efektif, efisien, sistematis, rasional, terkendali dan terpimpin untuk menjalankan segala kegiatan atau operasional organisasi. Organisasi merupakan sebuah system yang terdiri dari aneka subsistem, dimana manusia mungkin merupakan subsistem terpenting, dan masing-masing subsistem saling berinteraksi dalam upaya mencapai sasaran atau tujuan organisasi yang bersangkutan (Winardi, 2017).

Kesuksesan sebuah organisasi tidak lepas dari peran penting anggota yang ada di dalamnya, untuk bisa mencapai tujuan organisasi maka kualitas kinerja yang baik dari anggota pada bagiannya masing masing sangat dibutuhkan untuk menyukseskan sebuah organisasi. Dalam organisasi baik organisasi publik maupun organisasi bisnis memiliki penilaian terhadap kinerja organisasinya masing-masing. Hasil dari penilaian kinerja tersebut nantinya dapat menjadi rujukan untuk dilakukan evaluasi ke depannya, agar organisasi mampu meningkatkan kualitas organisasi dan SDM nya. Hasil penilaian tersebut juga dapat dijadikan referensi bagi organisasi terkait untuk melakukan perubahan dan inovasi dalam organisasi.

Kinerja merupakan prestasi kerja, dimana sebuah kinerja organisasi ini diperoleh karena hasil dari kerjasama seluruh komponen yang ada dalam organisasi untuk mewujudkan tujuan organisasi. Kinerja organisasi merupakan hasil kegiatan administrasi, dimana administrasi merupakan kegiatan kerja sama yang dilakukamn sekelompok orang dalam organisasi untuk mencapai tujuan.

Sekretaris Camat Johan Pahlawan mengatakan bahwa kinerja pegawai dalam organisasi Kantor Camat Johan Pahlawan sudah $80 \%$ baik dan tanggung jawab para pegawai dikantor sudah sepenuhnya dilaksanakan namun belum mencapai $100 \%$. Setiap pegawai baik atasan ataupun staff selalu bekerja berlandaskan pada SOP yang sudah di terapkan di kantor Camat Johan Pahlawan.

Pelayanan public adalah salah satu hak seluruh warga Negara, tanpa memandang strata social mereka. Oleh sebab itu sudah menjadi tugas dan kewajiban bagi pemerintah untuk memberikan pelayanan public yang berkualitas dalam berbagai bidang kehidupan. Namun sayangnya masih sering kali pelayanan yang diberikan oleh pemerintah tidak sesuai dengan harapan dan keinginan masyarakat untuk mendapatkan pelayanan public yang berkualitas. Hal tersebut disebabkan karena birokrat masih menempatkan masyarakat sebagai pihak yang "melayani" bukan yang seharusnya "dilayani".

Sementara itu dalam kehidupan politik, buruknya kualitas pelayanan publik akan memberikan dampak terhadap menurunnya kepercayaan masyarakat terhadap pemerintah. Kualitas pelayanan publik selama ini menjadi salah satu variabel penting untuk mendorong munculnya krisis kepercayaan masyarakat kepada pemerintah, yang kemudian dibuktikan dalam bentuk protes atau kritikan baik melalui media sosial maupun pemberitaan bahkan sampai pada aksi demonstrasi yang cenderung tidak sehat. Hal tersebut menadi indikasi bahwa masyarakat mengalami kefrustasian terhadap pemerintahnya. 
Pelayanan publik yang diselenggarakan oleh pemerintah baik dari pusat sampai kepada level paling bawah yaitu pemerintah desa kini dituntut untuk selalu prima dalam menyediakan pelayanan publik kepada masyarakat. Dalam hal ini Kantor kecamatan juga ikut ambil bagian yang cukup penting dalam proses penyelenggaraan pelayanan publik di tingkat daerah. Aceh Barat merupakan salah satu kabupaten yang saat ini terus berupaya mencapai prestasi nasional khususnya di bidang kinerja organisasi dan pelayanan publik. Pada tahun 2018 Aceh Barat mendapat predikat kepatuhan tertinggi terhadap standart pelayanan publik dari Ombudsman RI Tentunya penghargaan tersebut bukan hanya sekedar penghargaan, namun menjadi alarm yang selalu mengingatkan bagi seluruh organisasi publik di aceh Barat untuk selalu memaksimalkan pelayanan publiknya. Kantor Kecamatan Johan Pahlawan sebagai lokus dari penelitian ini adalah salah satunya yang juga wajib untuk menyediakan pelayanan prima kepada masyarakat yang tinggal di kecamartan Johan Pahlawan pada khususnya.

Adapun beberapa penelitian sebelumnya yang memiliki fokus yang sama yaitu mengkaji kinerja organisasi publik pada tingkat kecamatan namun dilhita dari sisi kinerja aparat kantor kecamatan dalam memberikan pelayana administrasi di Kecamatan Blangpidie Aceh Barat Daya oleh Walid Mustafa pada tahun 2015(Mustafa, 2015). Selain itu juga dari Z. Mukmin, $\mathrm{R}$ Ruslan, dkk mengkaji kinerja aparatur desa dalam pembangunan desa Suak Ribee dari sudut pandang masyarakat tahun 2018. (MUKMIN et al., 2018). Perbedaan dengan kajian penelitian ini adalah indicator yang digunakan untuk melihat kinerja organisasi kantor kecamatan Johan Pahlawan, faktororfaktor yang mempengaruhi kinerja organisasi dan lokus penelitian yang berbeda dibandingkan dengan penelitian sebelumnya.

Sedangkan penelitian ini diharapkan dapat memberikan kontribusi bagi pembaca dan pemerintah sebagai referensi dan masukan guna dilakukan penelitian selanjutnya ataupun sebagai bahan evaluasi bagi pemerintah. Tujuan penelitian ini untuk dapat mengetahui bagaimana kinerja organisasi dan faktorfaktor yang mempengaruhi kinerja Kecamatan Johan Pahlawan dalam mendukung pelayanan publik disana.

\section{METODE}

Metode Penelitian yang digunakan adalah penelitian deskriptif kualitatif dengan teknik pengumpulan data melalui studi kepustakaan (library reseach) dimana data melalui dokumen-dokumen aktual yang berkaitan dengan objek penelitian yaitu melalui makalah laporan penelitian, buku, jurnal dan dokumen- dokumen lain yang relevan. Kemudian diinterpretasikan dan disesuaikan dengan pertanyaan dalam penelitian, dalam hal ini teknik analisis data yang digunakan yaitu dengan cara mereduksi data, menyajikan data dan menarik kesimpulan (Miles dan Huberman dalam Silalahi, 2009).

\section{HASIL DAN PEMBAHASAN \\ Kinerja Organisasi Publik}

Secara etimologis, kinerja berasal dari kata dasar "kerja". Kinerja dalam organisasi merupakan jawaban dari berhasil atau tidaknya tujuan organisasi yang telah ditetapkan sebelumnya. Dimana pada dasarnya hal tersebut dapat dilihat dari dua sisi, yaitu kinerja organisasi dan kinerja pegawai. Kinerja adalah sebuah pencapaian hasil atau degree of accomplishment dimana kinerja organisasi dapat kita lihat dari tingkatan sejauh mana organisasi dapat mencapai tujuan sudah ditetapkan sebelumnya (Wahyudi, Adam, \& Mahdani, 2018)

Kinerja merupakan hasil dari kegiatan kerjasama antar anggota atau kompenen organisasi guna mewujudkan tujuan organisasi. Secara sederhana, kinerja merupakan produk dari kegiatan administrasi, yaitu kegiatan kerja sama dalam sebuah organisasi atau kelompok dalam mencapai tujuan yang pengelolaanya disebut dengan manajemen. Menurut Keban (1995) kinerja merupakan terjemahan dari "performance" yang sering diartikan sebagai penampilan, unjuk rasa atau prestasi. Kinerja merupakan tingkat pencapaian pelaksanaan suatu kegiatan, program, atau kebijakan dalam mencapai misi, visi sasaran serta tujuan organisasi yang telah disusun ke dalam perencanaan strategis organisasi baik organisasi sektor publik maupun bisnis.

Dari beberapa pengertian kinerja di atas, maka dapat kita dimpulkan bahwa kinerja adalah hasil pencapaian kerja yang telah dilakukan baik oleh individu maupun kelompok organisasi dalam pelaksanaan program, kegiatan, serta kebijakan untuk mewujudkan visi, misi, sasaran maupun tujuan organisasi yang sudah ditetapkan sebelumnya. Dalam pengelolaan sebuah organisasi tentunya membutuhkan sumber daya baik bersifat fisik maupun non fisik. Sumber daya fisik contohnya adalah peralatan, financial, energi dan manusia atau SDM, sedangkan non fisik contohnya ialah peraturan, informasi, dan kebijakan. Oleh sebab itulah kinerja organisasi juga dipengaruhi oleh sumber daya tersebut.

Kinerja organisasi bukan hanya dilakukan oleh organisasi bisnis melainkan juga organisasi publik. Kinerja organisasi publik dikatakan baik salah satu ukurannya adalah apabila pelayanan publik yang dilakukan dapat terselenggara dengan baik sesuai dengan SOP dan memberikan kepuasan pelayanan bagi masyarakat. Kemudian dari situlah dapat dilakukan pengukuran kinerja dengan menggunakan indikator-indikator kinerja untuk dapat mengetahui apakah organisasi publik tersebut sudah melaksanakan tugasnya dengan baik dan untuk mengetahui tujuannya sudah tercapai atau belum, khususnya dalam memberikan pelayanan publik kepada masyarakat.

Dalam suatu organisasi, penilaian kinerja terhadap organisasi merupakan hal yang sangat penting. Hal ini disebabkan antara kinerja dan penilaian kinerja merupakan hal yang tidak dapat dipisahkan. Adapun indikator yang dapat digunakan dalam pelaksanaan pengukuran kinerja organisasi sebagai berikut:

Masukan (input): segala sesuatu yang dibutuhkan agar pelaksanaan kegiatan nantinya mampu untuk menghasilkan keluaran atau output yang dapat berupa dana, SDM, Informasi kebijakan atau peraturan perundangan dan sebagainya.

Proses (process): segala upaya atau aktifitas yang dilakukan untuk mengolah masukan (input) menjadi keluaran (output).

Keluaran (output): segala sesuatu yang diharapkan langsung dapat dipakai dari suatu kegiatan yang telah dilakukan baik hasilnya berupa fisik maupun non fisik.

Hasil (outcome): berfungsinya keluaran kegiatan atau hasil nyata dari keluaran (output) suatu kegiatan yang dihasilkan

Manfaat (benefit): segala tujuan akhir dari pelaksanaan kegiatan. Dimana hal tersebut memberikan gambaran manfaat yang diperoleh dari indikator hasil dan diharapkan untuk dapat tercapai secara optimal.

Dampak (impact): pengaruh positif dan negatif yang timbul dari manfaat hasil kegiatan. Tentunya pengaruh tersebut dapat 
diketahui dalam jangka waktu menengah atau panjang.

Sementara itu keberhasilan suatu organisasi publik juga sangat dipengaruhi oleh kinerja dari aparat publiknya. Oleh sebab itu organisasi publik selalu berusaha untuk meningkatkan kinerja pegawainya dalam mencapai tujuan yang telah ditetapkan, mengingat bahwa kualitas sumber daya manusia menjadi faktor utama penentu keberlangsungan dan kemajuan bagi suatu organisasi, karena dengan sumber daya itulah organisasi mampu menjalani segala aktivitas maupun kegiatan serta mengelola sumber daya yang ada seoptimal mungkin.

Sumber daya manusia merupakan faktor sentral dalam suatu organisasi Visi organisasi dibuat untuk kepentingkan manusia dan misinya dikelola dan diurus oleh manusia (Siagian, 2011). Cateora dan Graham (2007) yang mendefinisikan bahwa kualitas (quality) dibedakan kedalam dua dimens yaitu kualitas dari prospek pasar dan kualitas kinerja.

Sehubungan dengan kualitas kinerja, bukan hanya perusahaan saja yang melakukan penilaian kinerja, namun organisasi publik juga melakukan hal yang sama. Kinerja organisasi publik menurut Agus Dwiyanto (Dwiyanto, 2005) berdasar adanya indikator yang secara lebih lanjut dijelaskan sebagai berikut:

\section{Produktivitas}

Produktivitas tidak hanya mengukur tingkat efisiens dan efektivitas pelayanan. Produktivitas pada umumnya dipahami sebagai rasio antara input dan output. Dalam indikator ini melihat seberapa besar pelayanan publik memberikan hasil yang diharapkan.

\section{Kualitas Layanan}

Kualitas layanan menjadi penting dalam menjelaskan kinerja organisasi pelayanan publik. Hal tersebut berawal dari masih adanya ketidakpuasan masyarakat terhadap kualitas layanan oleh pemerintah yang diterima masyarakat.

\section{Responsivitas}

Responsivitas merupakan kemampuan organisasi untuk mengetahui apa saja yang menjadi kebutuhan, tuntutan dan harapan masyarakat. Diharapkan program maupun kegiatan yang dilakukan oleh pemerintah mampu memenuhi kebutuhan, tuntutan dan keinginan masyarakat. Responsivitas secara langsung menggambarkan kemampuan organisasi publik dalam menjalankan misi dan tujuannya. Responsivitas yang rendah menandakan bahwa ada ketidakselarasan antara pelayanan dengan kebutuhan masyarakat. Responsivitas yang rendah maka kinerja organisasi publikpun juga dikatakan kurang baik, karena visi dan misi nya tidak dapat tercapai sepenuhnya.

\section{Responsibilitas}

Pelaksanaan semua kegiatan dalam organisasi publik harus sesuai dengan prinsip-prinsip administrasi yang benar atau sesuai dengan kebijakan organisasi, sehingga terkadang responsibilitas berbenturan dengan responsivitas.

\section{Akuntabilitas}

Akuntabilitas Publik melihat bahwa kebijakan dan kegiatan pemerintah tunduk pada pejabat publik. Dimana pejabat publik yang tak lain juga merupakan pejabat politik yang mendapatkan jabatannya karena dipilih oleh rakyat. Sehingga harapannya setiap pejabat menyadari bahwa segala yang mereka lakukan tak lain adalah untuk memenuhi aspirasi rakyat, menempatkan kepentingan rakyat di tempat yang utama. Oleh sebab itulah akuntabilitas publik melihat seberapa besar manfaat yang diberikan sebuah kebijakan atau kegiatan pemerintah kepada masyarakat. Dengan begitu maka kinerja organisasi publik dinilai juga dari sisi eksternal organisasi, seperti nilai dan norma dalam masyarakat. Organisasi publik memiliki akuntabilitas yang tinggi apabila kegiatan maupun kebijakan sudah benar dan sesuai dengan nilai dan norma yang berkembang di masyarakat

\section{Pelayanan Publik}

Pelayanan publik merupakan segala bentuk pelayanan barang ataupun jasa publik yang diberikan oleh instansi pemerintah baik pusat maupun daerah guna memenuhi kebutuhan dan kepentingan masyarakat sesuai dengan peraturan yang berlaku. Sama halnya dengan definisi pelayanan publik dalam Kepmenpan No. 63/KEP/M.PAN/7/2003. Semakin dipertegas lagi dengan definisi yang diberikan melalui UndangUndang Nomor 25 Tahun 2009 bahwa pelayanan publik sebagai kegiatan atau rangkaian kegiatan untuk memenuhi kebutuhan pelayanan sesuai dengan perundangundangan bagi setiap warga negara dan penduduk atas barang, jasa, dan/atau pelayanan administratif yang disediakan oleh penyelenggara pelayanan publik.

Oleh sebab itu sudah menjadi tugas dan kewajiban bagi aparatur Negara maupun birokrat untuk memberikan pelayanan yang berkualitas dan professional, mengingat saat ini kondisi masyarakat kita dinamis dan makin banyak yang menyadari bahwa sudah menjadi hak mereka untuk mendapatkan pelayanan publik yang baik dari pemerintah bukan hanya dilihat dari sisi kesamaannya saja, tapi pelayanan publik diharapkan dapat terselenggara dengan responsive, mudah, cepat, transparan dan tepat. Tentunya bukan hanya dari cara penyelenggaraannya saja namun dari peningkatan kemampuan dan kompetensi dari aparatur penyelenggara pelayanan publik juga harus selalu ditingkatkan. Tujuan akhir dari pelayanan publik bukan hanya sekedar memenuhi kebutuhan maupun kepentingan masyarakat, namun lebih jauhnya mampu untuk meningkatkan kualitas masyarakat untuk dapat menentukan masa depannya sendiri.

Pada dasarnya pelayanan publik bukan hanya sekedar transportasi umum, ketersediaan infrastruktur yang memadahi namun menyangkut berbagai aspek kehidupan baik aturan maupun pemenuhan kebutuhan masyarakat di bidang kesehatan, pendidikan, sarana dan prasarana, ekonomi dan sebagainya.

Pemerintah Indonesia sendiri sudah berupaya sejak lama untuk memperbaiki pelayanan publik. Salah satunya ialah melalui kebijakan pemerintah dalam Surat Keputusan Menteri Pendayagunaan Aparatur Negara Nomor 81/1993 tentang Pedoman Tatalaksana Pelayanan Umum. Kemudian Inpres No. 1 Tahun 1995 tentang perbaikan dan peningkatan mutu pelayanan aparatur pemerintah kepada masyarakat. Kemudian selanjutnya diterbitkan Keputusan Menpan Nomor 63/KEP/M.PAN/ 7/2003 tentang Pedoman Umum Penyelenggaraan Pelayanan Publik. Dan kini di era pemerintahan Joko Widodo ada bebrapa inovasi yang dilakukan oleh bebrapa pemerintah daerah untuk meningkatkan kualitas pelayanan publik salah satunya yaitu dengan penyelenggaraan Mal Pelayanan Publik yang sudah terbentuk di 17 kota/kabupaten di Indonesia.

Penyelenggaraan pelayanan publik di Indonesia di beberapa daerah maupun lembaga pemerintahan masih memiliki berbagai 
kelemahan seperti kurang responsif, kurang informatif, kurang memberikan kemudahan akses bagi masyarakat, kurang mau mendengar keluhan/saran/aspirasi masyarakat, kurang koordinasi, birokratis, dan inefisiensi. Kemudian jika dari sisi aparaturnya masih lemah pada profesionalisme, kompetensi, emphaty dan etika.

Tentunya upaya meningkatkan kualitas pelayanan tidak hanya ditempuh melalui keputusan-keputusan saja, tetapi juga melalui peningkatan kemampuan aparatur dalam memberikan pelayanan. Upaya ini dapat dilakukan dengan cara memberikan berbagai materi mengenai manajemen pelayanan dalam diklatdiklat struktural pada berbagai tingkatan, selain itu dengan adanya monitoring serta evaluasi secara berkala baik secara internak organisasi maupun eksternal organisasi publik, sehingga nantinya hasil evaluasi tersebut dapat dijadikan sebagai bahan koreksi untuk nantinya dilakukan perbaikan dan pembaharuan atau inovasi pelayanan publik.

\section{Kinerja Kecamatan Johan Pahlawan dalam penyelenggaraan pelayanan publik. \\ Produktivitas}

Penyelenggaraan pelayanan publik di kantor kecamatan Johan Pahlawan sesuai dengan standar prosedur yang telah ditetapkan, dan jenis layanan yang diberikan juga telah sesuai dengan peraturan yang ada. Kemudian setiap kegiatan sudah diatur dalam PPA yang sudah dirancang sebelumnya, kecuali ada perubahan dari Gampong (sudah memiliki program dan perencanaan yang baru). Contoh kegiatan yang dilakukan seperti musrembang yang beberapa bulan lalu dilakukan. Dalam musrembang terdapat perwakilan dari setiap Gampong dan ada banyak program yang diajukan dari setiap Gampong, namun hanya beberapa yang bisa diterima ( penting) untuk dinaikkan ke kecamatan, lalu dikeluarkan kebijakan dari Kabupaten apakah layak dilaksanakan programnya atapun tidak, dan jika dilaksanakan maka akan diputuskan kapan dilaksankan dan berakhir program tersebut.

\section{Kualitas Pelayanan}

Ada beberapa permasalahan yang terjadi dalam proses penyelenggaraan pelayanan public di kantor Kecamatan Johan Pahlawan khususnya di bagian meja depan pelayanan, dimana beberapa pegawai disana kurang disiplin dan juga tingkat pendidikan mereka rata-rata lulusan SMA sehingga terbatas pula kempuan mereka dalam mengaplikasikan komputer.

Namun hal ini tidak dibiarkan saja oleh Camat Johan Pahlawan. Pimpinan langsung memberikan teguran kepada pegawai yang tidak disiplin dan akan diberikan sanksi, lalu jika pegawai tersebut masih melakukan kesalahan secara terusmenerus maka Bupati Aceh Barat yang akan langsung menanganinya.

Selain itu juga permasalahan terdapat didalam Gampoeng dimana kuechik dan aparaturnya berselisih paham, sehingga berdampak pada pemberian layanan yang kurang baik kepada masyarakat.

\section{Responsivitas}

Penyelenggaraan Pelayanan dikantor kecamatan Johan Pahlawan tidak hanya muncul dari pegawainya saja tetapi juga dari segi sarana dan perasarana yang kurang memadai. Mengingat letak Kantor Camat berada dipusat kota, sehingga hampir setiap hari warga datang dengan berbagai keperluan, tetapi dengan terbatasnya sarana dan perasarana menyebabkan waktu yang lama dalam memenuhi kebutuhan masyarakat. Sehingga apa yang dibutuhkan dan apa yang diharapkan oleh masyarakat terhadap pelayanan publik di kantor Kecamatan Johan pahlawan kurang dapat diberikan secara maksimal oleh Kecamatan Johan Pahlawan. Tentunya hal tersebut berpengaruh terhadap kinerja pegawai dalam melayani masyarakat.

\section{Responsibilitas}

Setiap orang yang bekerja dikantor Kecamatan Johan Pahlawan tidak harus berlulusan sarjana, rata-rata pegawai di Kecamatan Johan pahlawan adalah berlulusan SMA. Namun $75 \%$ para pegawai ditempatkan pada bidangnya masing-masing sesuai dengan latar belakang pendidikannya. Pimpinan sangat memperhatikan setiap keterampilan yang dimiliki pegawainya. Responsibilitas pegawai Kantor Camat Johan Pahlawan, terhadap pekerjaan mereka masing-masing sudah baik tetapi belum sepenuhnya mencapai $100 \%$. Para pegawai juga sudah mampu menselaraskan setiap kewenangan yang diberikan kepada mereka terutama dalam menjalankan UU No 32 tahun 2004.

Selain itu juga terdapat kelemahan sumber daya manusia aparatur pemerintah dalam memberikan pelayanan disebabkan oleh sistem kompensasi yang rendah dan tidak tepat, seperti yang terjadi di kecamatan Johan Pahlawan tersebut

\section{Akuntabilitas}

Pertanggung jawaban yang dilakukan oleh Kantor Kecamatan Johan Pahlawan masih bersifat internal organisasi, di mana hal tersebut dilakukan sesuai dengan rantai komando dan struktur organisasi. Belum pernah dilakukan akuntabilitas keluar kepada masyarakat melalui media online seperti website internal organisasi, karena memang Kantor kecamatan Johan Pahlawan belum memilki webisite sendiri.

\section{Faktor-faktor yang mempengaruhi kinerja pegawai dikantor Camat Johan Pahlawan \\ Peralatan dan teknologi yang digunakan}

Hal ini sangat berpengaruh terhadap kinerja pegawai dimana pegawai kantor Kecamatan Johan Pahlawan belum sepenuhnya mengetahui penggunaan teknologi yang ada seperti komputer secara maksimal

\section{Kondisi internal pegawai sendiri}

Ketidak disiplinan pegawai akan menjadi penghambat proses pekerjaan dikantor Camat Johan Pahlawan sehingga berdampak buruk pada kinerja pelayanan terhadap masyarakat. dan sistem kerja pegawai dikantor Camat Johan Pahlawan berlandaskan kepada SOP, bahkan Gubenur Aceh pernah menegur langsung mengenai kinerja, kebersihan dan keindahan di Kantor Kecamatan Johan Pahlawan.

Sarana dan perasarana yang kurang memadai

Sarana dan perasaranan dikantor Kecamatan Johan Pahlawan masih tergolong belum lengkap, misalnya seperti komputer, transportasi pegawai, ac, ATK dan lain-lain. Hal ini sangatlah berpengaruh terhadap kinerja pegawai, dimana ketika pegawai ingin mengerjakan tugasnya maka haruslah didukung dengan peralatan yang lengkap, jika peralatan yang dibutuhkan masih belum terpenuhi maka tugasnya tidak akan terkerjakan dengan maksimal. 


\section{KESIMPULAN}

Kinerja kantor Kecamatan Johan Pahlawan dinilai dari lima indicator yaitu Produktivitas, Kualitas Layanan, Responsivitas, Responsibiliti dan akuntabilitas. Produktivitas kantor kecamatan johan pahlawan dilihat dari program dan kegiatan yang dilakukan sesuai dengan perencanaan yang dilakukan. Lalu dalam penyelenggaraan pelayanan publik di kantor kecamatan Johan Pahlawan sesuai dengan standar prosedur yang telah ditetapkan, dan jenis layanan yang diberikan juga telah sesuai dengan peraturan yang ada. Kulitas pelayanan publik sudah diberikan sesuai prosedur walupun terkadang masih ada beberapa kekurangan karena kurangnya disiplin dari bebrapa pegawai di kantor kecamatan Johan pahlawan dan keterbatasan sarana dan prasarana serta kemampuan dari pegawai dalam mengoperasikan komputer. Responsibilitas pegawai Kantor Camat Johan Pahlawan, terhadap pekerjaan mereka masingmasing sudah baik tetapi belum sepenuhnya mencapai $100 \%$. Para pegawai di Kecamatan Johan Pahlawan kurang disiplin dan juga yang ditetapkan dibagian pelayanan rata-rata lulusan SLTA sehingga terbatasnya pengetahuan para pegawai tersebut dalam mengaplikasikan computer. Responsivitas melihat dari apa yang dibutuhkan dan apa yang diharapkan oleh masyarakat terhadap pelayanan publik di kantor Kecamatan Johan pahlawan kurang dapat diberikan secara maksimal oleh Kecamatan Johan Pahlawan. Akuntabilitas sebatas internal organisasi saja sesuai dengan rantai komando dan struktur organisasi.

Faktor-faktor yang mempengaruhi kinerja pegawai dikantor Camat Johan Pahlawan adalah perkembangan teknologi semakin cepat, kondisi internal pegawai dimana masih terdapat kelemahan dalam memberikan pelayanan disebabkan oleh sistem kompensasi yang rendah dan tidak tepat, serta sarana dan prasarana kurang memadai.

\section{REFERENSI}

Aditya, Aulia Rama, Riski, Irwandi, dkk. (2019). Makalah Kinerja Organisasi Dalam Kantor Camat Johan Pahlawan Kota Meulaboh. Meulaboh

Dewanti, D. A. (2014). Studi Tentang Kinerja Pelayanan Publik di Kantor Kecamatan Samarinda Ulu. eJournal Ilmu Pemerintahan, 02.

Dwiyanto, A. (2005). Mewujudkan Good Melalui Pelayanan Publik. Yogyakarta : Gadjah Mada University Press.

Fadhilah, A. (2014, Oktober 14). Ahmad Fadhilah. Retrieved Desember 2, 2019, from https://ahmadfadilah09.blogspot.com/2014/10/arti-pentingorganisasi-dalam $76 . \mathrm{html}$

Keban, Y. T. (1995). Indikator Kinerja Pemda: Pendekatan Manajemen Dan Kebijakan. Yogyakarta: FISIP UGM.

Kinerja Organisasi. (2012, Oktober 5). Retrieved November 30, 2019, from Rarajonggrang: https://raraajonggrang.blogspot.com/2012/10/kinerjaorganisasi.html

Mukmin, Z., Ruslan, R., \& Kurniati, S. (2018). Persepsi Masyarakat Terhadap Kinerja Aparatur Desa Dalam Penyelenggaraan Pembangunan Di Desa Suak Ribee Kecamatan Johan Pahlawan Kabupaten Aceh Barat. Jurnal Ilmiah Pendidikan Pancasila Dan Kewarganegaraan. https://doi.org/10.17977/um019v3i12018p106

Mustafa, W. (2015). Kinerja Aparat Kantor Camat Memberikan Pelayanan Administrasi Kepada Masyarakat Di Kecamatan
Blangpidie Aceh Barat Daya. Jurnal Administrasi Publik.

Mahsyar, A. (2011). Masalah Pelayanan Publik di Indonesia dalam Perspektif Administrasi Publik. Otoritas, 1 .

Robbins, S. P. (1994). Teori Organisasi : Struktur, Desain dan Aplikasi. Jakarta: Arcan.

Rosidah. (n.d.). Upaya Peningkatan Kualitas Pelayanan Dalam Organisasi. Retrieved Desember 03, 2019, from staffnew.uny.ac.id: http://staffnew.uny.ac.id

Silalahi, U. (2009). Metode Penelitian Sosial. Bandung: Refika Aditama.

Suprapto, H. (2016, Desember 16). Ekonomi Dan Manajemen. Retrieved Desember 2, 2019, from Unikarta.blogspot: https://unikarta.blogspot.com/2016/12/pengaruhpenerapan-analisis-jabatan.html

Wargadinata, E. (2017). Kualitas Pengukuran Kinerja Organisasi Publik. Sosiohumaniora, 19.

Wibowo. (2007). Manajemen Kinerja. Jakarta: Raja Grafindo Persada.

Winardi, J. (2017). Teori Organisasi \& Pengorganisasian. Rajagrafindo Persada. 